\title{
Exploring the potential hazard of Mycobacterium avium subspecies paratuberculosis as a cause for Crohn's disease
}

\author{
Sukumar Bharathy, Lakshmanasami Gunaseelan and Kannan Porteen \\ Department of Veterinary Public Health and Epidemiology, Madras Veterinary College, Chennai - 600 007, Tamil Nadu, \\ India. \\ Corresponding author: Sukumar Bharathy, e-mail: bharathy.vet@gmail.com, \\ Co-authors: LG: deanvcri@tanuvas.org.in, KP: rajavet2002@gmail.com \\ Received: 06-12-2016, Accepted: 02-03-2017, Published online: 28-04-2017
}

doi: 10.14202/vetworld.2017.457-460 How to cite this article: Bharathy S, Gunaseelan L, Porteen K (2017) Exploring the potential hazard of Mycobacterium avium subspecies paratuberculosis as a cause for Crohn's disease, Veterinary World, 10(4): 457-460.

\begin{abstract}
Background: Mycobacterium avium subspecies paratuberculosis (MAP) is the causative agent of Johne's disease (JD), or paratuberculosis in ruminants has been suspected to be implicated in the pathogenesis of Crohn's disease (CD) in humans with chronic inflammatory intestinal changes. As the hypothesis is now fast being recognized that MAP could possibly be the etiological agent of CD which is found to be excreted in milk of dairy animals subclinically or terminally ill with JD.
\end{abstract}

\begin{abstract}
Aim: The present study was aimed to detect MAP in milk by polymerase chain reaction (PCR) targeting IS900 and to describe the excretion pattern of MAP in milk from asymptomatic lactating cows and does with relevance to the public health significance.
\end{abstract}

Materials and Methods: A total of 77 milk samples were collected randomly from lactating animals which include cows (45) and does (32). All the 77 milk samples were processed to identify the presence of MAP by employing the direct IS900 PCR as per the standard protocol.

Results: Out of 77 milk samples from asymptomatic lactating animals, 12 (15.58\%) were showed positivity for IS900 PCR in which 5 (11.11\%) were from lactating cows and 7 (21.87\%) were from lactating does.

Conclusion: In our study, $15.58 \%$ of milk samples showed IS 900 positivity which indicates the presence of subclinical MAP infection in lactating animals. Hence, there is a possibility for excretion of MAP through milk which can be a potential threat for CD in humans by raw milk consumption. Therefore, the prevention of MAP in the food chain need to be assured by sourcing raw products from animal herds free of MAP infection.

Keywords: Crohn's disease, excretion, food chain, IS900 polymerase chain reaction, Mycobacterium avium subspecies paratuberculosis, raw milk.

\section{Introduction}

Crohn's disease (CD) is one of a group of inflammatory bowel diseases that also includes ulcerative colitis. CD was first described in 1932 as a chronic inflammation of the terminal ileum [1]. In some areas in the USA in recent years, the incidence of CD is around $7-8$ per $10^{5}$ populations per year [2]. No convincing explanation for the pathogenesis of $\mathrm{CD}$ currently exists; however, various environmental factors (e.g., pathogenic or non-pathogenic microbes, lifestyle, hygiene factors, diet, and stress) have been suggested as a cause for CD [3,4]. Mycobacterium avium subspecies paratuberculosis (MAP) is suspected as one of the causes for CD. MAP causes a disease in dairy cows and other animals that are similar to $\mathrm{CD}$, called Johne's disease (JD) or paratuberculosis [5],

Copyright: Bharathy, et al. Open Access. This article is distributed under the terms of the Creative Commons Attribution 4.0 International License (http://creativecommons.org/licenses/ by/4.0/), which permits unrestricted use, distribution, and reproduction in any medium, provided you give appropriate credit to the original author(s) and the source, provide a link to the Creative Commons license, and indicate if changes were made. The Creative Commons Public Domain Dedication waiver (http:// creativecommons.org/publicdomain/zero/1.0/) applies to the data made available in this article, unless otherwise stated. and MAP has been isolated in intestinal tissues of CD patients, thus giving rise to a hypothesis of there being a possible link between these two diseases [6]. Several studies have reported contrasting observations regarding the association of MAP and CD in humans. India has been an endemic area for intestinal tuberculosis in humans as well as JD in ruminants. Conventionally, India has been considered as a low prevalence area for $\mathrm{CD}$. However, in the last decade, there has been a rapid increase in the prevalence of inflammatory bowel disease in India and other Asian countries [7].

MAP is shed intermittently by subclinically and clinically affected animals into feces and milk and colostrum and viable MAP has been also isolated from such animals [8]. MAP isolation from milk was first reported in 1935, in association with advanced clinical paratuberculosis. More recent studies have found MAP isolation rates in milk of up to $28 \%$ in clinically affected cows from State of Pernambuco, Brazil [9] and 48\% in colostrums from the dam-daughter pairs given birth/being born on eight commercial dairy farms with endemic paratuberculosis located in Friesland [10] and $12 \%$ in milk of subclinical cases of bovines from Pennsylvania [11], with MAP DNA 
detection in pasteurized milk samples purchased from retail markets [12]. At present, it is not known whether commercial pasteurization effectively kills MAP in contaminated raw milk [12]. MAP has been identified in milk samples of dairy lactating animals with a history of JD by nested IS 900 polymerase chain reaction (PCR) and this bacterium can survive pasteurization [13]. A link between MAP, CD, and consumption of dairy products from raw milk is still to be demonstrated [14]. PCR is a rapid and sensitive method for the detection of MAP in milk and other types of samples [15].

Therefore, the study was aimed to detect MAP in milk by PCR targeting IS900 and to describe the excretion pattern of MAP in milk from asymptomatic lactating cows and goats with relevance to the public health significance.

\section{Materials and Methods \\ Ethical approval}

There were no live animals used in this study; hence, there is no ethical approval necessary.

\section{Study population}

A total of 77 milk samples were collected from organized dairy farms and the Madras Veterinary College (MVC) Teaching Hospital, Chennai, which included 45 lactating cow and 32 lactating does. None of these animals had been systematically examined for paratuberculosis by serology or fecal culture.

\section{Milk sampling}

Before collection of milk, the teats were thoughtfully cleaned with warm water to avoid sample contamination from skin and feces. Milk samples $(5-10 \mathrm{ml})$ were collected in a $10 \mathrm{ml}$ (with V-shaped bottom) sterile graduated tube from all the quarters of each lactating animals (cows and does) by hand milking, discarded the first 1-2 $\mathrm{ml}$ and the samples were transported to laboratory of the Department of Veterinary Public Health and Epidemiology, MVC, Chennai, and refrigerated at $4{ }^{\circ} \mathrm{C}$ until analysis, i.e., within $24 \mathrm{~h}$ from collection.

\section{Sample processing for DNA extraction}

The milk samples were centrifuged at $3000 \mathrm{rpm}$ for $15 \mathrm{~min}$ and the supernatant, including the hardened fat cream layer, was aspirated and discarded, except pellet. The resultant pellet was washed thrice in phosphate-buffered saline $(\mathrm{pH} 7.3)$ and centrifuged at $1000 \mathrm{rpm}$ for $10 \mathrm{~min}$. DNA was extracted from the pellet using commercial kit (DNA extraction kit, Qiagen, Hilden, Germany). The final product was stored at $-20^{\circ} \mathrm{C}$ for subsequent PCR.

\section{PCR}

IS900 PCR was performed as per the procedure described by Pillai and Jayarao [16] using two primers. 5'primer sequence was 5' - CCGCTAATTGA GA GATGCGATTGG-3' and the 3' primer sequence was 5'AATCAA CTCCAGCAGCAGCGCGGCCTCG-3' for detection of insertion sequence of 900 (IS900) of MAP which amplifies a $229 \mathrm{bp}$ fragment. PCR reaction volume was set to $25 \mu 1,12.5 \mu 1 \times 2$ Master Mix (Ampliqon, Denmark), $1 \mu \mathrm{l}$ of both forward and reverse primer (10 pmole $/ \mu \mathrm{l})$, and $4 \mu \mathrm{l}$ DNA template and remaining volume where adjusted with nuclease free water. Thermal cycling was performed in a Eppendorf thermal cycler (Hamburg, Germany) and cycling conditions were as follows, initial denaturation at $94^{\circ} \mathrm{C}$ for $3 \mathrm{~min}$, followed by 35 cycles for denaturation at $94^{\circ} \mathrm{C}$ for $1 \mathrm{~min}$, annealing of primers at $55^{\circ} \mathrm{C}$ for $1 \mathrm{~min}$, extension at $72^{\circ} \mathrm{C}$ for $1 \mathrm{~min}$, and final extension at $72^{\circ} \mathrm{C}$ for $7 \mathrm{~min}$.

\section{Agarose gel electrophoresis}

The resulting PCR amplified products were electrophoresed in $1.5 \%$ agarose using sodium borate buffer ( $\mathrm{pH}$ 8.2) (Fisher Scientific, India) with constant voltage of $100 \mathrm{~V}$ for $2 \mathrm{~h}$. The DNA fragments were stained with ethidium bromide $(1 \mathrm{mg} / \mathrm{ml})$ and were visualized using ultraviolet-transilluminator. The size of the amplified product was checked by molecular weight DNA marker, 100 bp ladder $\left(\mathrm{GeNei}^{\mathrm{TM}}\right.$, Bengaluru). The presence or absence of a $229 \mathrm{bp}$ fragment was recorded.

\section{Results}

Out of 77 milk samples collected from asymptomatic lactating dairy cows and does, $12(15.58 \%)$ were IS900 PCR-positive, which included $5(11.11 \%)$ lactating cows and 7 (21.87\%) lactating does. Agarose gel analysis of the amplified products size of $229 \mathrm{bp}$ considered as positive (Figures-1 and 2). The PCR products, however, differed in intensity. The differences in the intensity of the PCR-amplicons may be due to different concentrations of MAP in the randomly collected milk samples. This observation employing the most sensitive and rapid PCR-based test is clear evidence of MAP excretion in subclinically infected animals and offers the potential for spread to suckling young and possibly humans consuming raw milk.

\section{Discussion}

This study was undertaken to prove the excretion of MAP in milk from lactating asymptomatic animals by PCR targeting IS900 gene and to correlate the health risk associated with the consumption of milk and milk products from these animals. The most important routes of access of MAP to the food chain appear to be contaminated milk and milk products from infected ruminants [15]. Results of our study showed $15.58 \%$ positivity by IS 900 PCR indicated an evidence regarding the excretion of MAP organisms in milk and helped us to identify the subclinical carriers in general population of animals. In the past decade, several methods for the detection, isolation, and identification of MAP in milk have been described and most frequent method of MAP detection in milk is PCR [17]. The insertion element IS900 is the mostly used target for identification and also differentiation of MAP from other mycobacteria [18]. In 


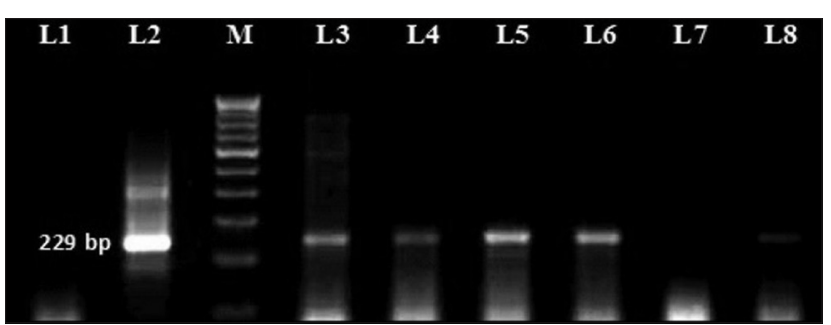

Figure-1: Mycobacterium avium subspecies paratuberculosis-specific amplicons (229 bp) using IS900 specific primers in goat milk samples. M: Molecular weight DNA marker, 100 bp ladder; Lane 1: Negative control; Lane 2: Positive control; Lane 3,4,5,6 and 8: DNA test samples.

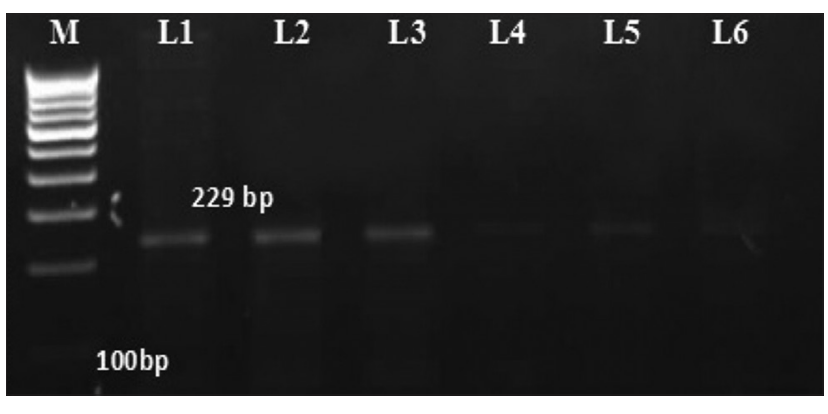

Figure-2: Mycobacterium avium subspecies paratuberculosis specific amplicons (229 bp) using IS900 specific primers in cow milk samples. M: Molecular weight DNA marker, 100 bp ladder; Lanes 1-6: DNA test samples.

a similar fashion, many studies have been conducted utilizing IS900 PCR to screen MAP organisms from bovine milk samples showed 3.6\% (8/222) [19], 3.4\% (29/851) positive [20], 7.8\% [21], and 19.7\% [22]. We have conducted similar kind of study in milk samples from 15 JD positive goats to establish the usefulness of milk as a non-invasive sample and we have detected MAP DNA in all 15 milk samples (100\%), four nucleotide sequences were deposited in the GenBank with accession numbers of KJ882900 to KJ882903 [17]. Variation of results between researchers worldwide may be attributed to the fact that the samples were collected from the general population including the healthy animals, further the shedding of MAP organisms at detectable levels in milk is irregular and intermittent [23] and fecal contamination during sampling or udder invasion through the teat channel or as a result of systemic dissemination [24,25]. In our study, the detection of positives was higher hinting an obviously endemic environment since raw milk may also be contaminated with feces during the milking process. The feces can contain at least $10^{6}$ colony forming units per gram, indicating that fecal contamination of milk may be a critical point at which MAP can enter the food supply [26].

In addition, many reports worldwide has shown that dairy products are made from raw milk or milk that has been subjected to heating treatments less severe than those used for pasteurization [27-29]. Current commercial pasteurization standards may reduce number of viable MAP but do not ensure destruction of all bacilli [30]. A study by Stabel and Lambertz [12] demonstrated that MAP present in raw milk and can survive subpasteurization heating treatments; In India, Shankar et al. [31] reported a high presence of MAP in pooled raw milk (44\%), commercially pasteurized milk $(67 \%)$, and milk products $(56 \%)$ indicating the survivability of these organisms even after heat treatment and risk associated with the consumption of milk and milk products from infected animals.

This study attempted to establish a causal relationship between MAP and CD by identifying the possible potential hazard of transmission through milk. Consumption of unpasteurized milk or milk products represents a low proportion of total milk intake; therefore, the extent raw milk could expose a population to MAP is limited. However, it still can be hypothesized that unpasteurized products have a greater amount of viable MAP than pasteurized products, and hence, the practice of consuming unpasteurized milk products may increase the exposure of a person to MAP, which may increase the risk of that person developing CD.

\section{Conclusion}

Routine screening of animals for MAP by utilizing non-invasive milk sample will help us to identify subclinical carriers and major route of transmission of the disease through milk can be prevented by adopting appropriate methods such as proper pasteurization of milk and milk products. Results of our study clearly proved the excretion of MAP organisms in milk which needs further investigation to elucidate the role of MAP as a potential threat to humans and to devise strict biosecurity measures to combat the disease in both animals and humans.

\section{Authors' Contributions}

SB carried out sample collection, sample processing, and drafting the manuscript. LG supervised the research work. KP provided guidance for the research work and revised the manuscript. All authors read and approved the final manuscript.

\section{Acknowledgments}

We are thankful to the PGRIAS Kattupakkam and Department of Clinics, MVC, Chennai, for sample collection and they are grateful to Tamil Nadu Veterinary and Animal Sciences University, Chennai, for contribution of the fund for this study under the Department of Veterinary Public Health and Epidemiology, MVC, Chennai.

\section{Competing Interests}

The authors declare that they have no competing interests.

\section{References}

1. Thompson, D.E. (1994) The role of mycobacteria in Crohn's disease. J. Med. Microbiol., 41: 74-94.

2. Herrinton, L.J., Liu, L., Lewis, J.D., Griffin, P.M. and Alliso, J. (2008) Incidence and prevalence of inflammatory bowel disease in a Northern California managed care 
organization. Am. J. Gastroenterol., 103: 1998-2006.

3. Momotani, E., Ozaki, H., Hori, M., Yamamoto, S., Kuribayashi, T., Eda, S. and Ikegami, M. (2012) Mycobacterium avium subsp. paratuberculosis lipophilic antigen causes Crohn's disease - Type necrotizing colitis in mice. Springer Plus, 1: 47.

4. Neuman, M.G. and Nanau, R.M. (2012) Inflammatory bowel disease: Role of diet, microbiota, life style. Transl. Res., 160(1): 29-44.

5. Naser, S.A., Sagramsingh, S.R., Naser, A.S. and Thanigachalam, S. (2014) Mycobacterium avium subspecies paratuberculosis causes Crohn's disease in some inflammatory bowel disease patients. World J. Gastroenterol., 20(23): 7403-7415.

6. Singh, S. and Gopinath, K. (2011) Mycobacterium avium subsp. paratuberculosis and Crohn's regional ileitis: How strong is association? J. Lab. Physicians, 3(2): 69-74.

7. Khan, I.A., Pilli, S., Rampal, A.S., Chauhan, S.K., Tiwari, V., Mouli, V.P., Kedia, S., Nayak, B., Das, P., Makharia, G.K. and Ahuja, V. (2016) Prevalence and association of Mycobacterium avium subspecies paratuberculosis with disease course in patients with ulcero-constrictive ileocolonic disease. PLOS One, 11(3): e 0152063.

8. Patel, A. and Shah, N. (2011) Mycobacterium avium subsp. paratuberculosis-incidences in milk and milk products, their isolation, enumeration, characterization, and role in human health. J. Microbiol. Immunol. Infect., 44: 473-479.

9. Albuquerque, P.P.F., Santos, A.S., Souza, N., Orestes, L., Kim, P.C.P., Cavalcanti, E.F.T., de Oliveira, J.M.B., Mota, R.P. and Júnior, J.W.P. (2017) Detection of Mycobacterium avium subsp. paratuberculosis in bovine milk from the state of Pernambuco, Brazil. Braz. J. Microbiol., 48(1): 113-117.

10. Eisenberg, S.W.F., Rutter, V.P.M. and Koets, A.D.P. (2015) Dam Mycobacterium avium subspecies paratuberculosis (MAP) infection status does not predetermine calves for future shedding when raised in a contaminated environment: A cohort study. Vet. Res., 46: 70.

11. Pinedo, J., Joseph, E., Gilles, R.G., Rae, D.O. and Claus, D. (2008) Mycobacterium paratuberculosis shedding into milk: Association of ELISA seroreactivity with DNA detection in milk. Int. J. Appl. Res. Vet. Med., 6: 137-144.

12. Stabel, J.R. and Lambertz, A. (2004) Efficacy of pasteurization conditions for the inactivation of Mycobacterium avium subsp. Paratuberculosis in milk. J. Food Prot., 67(12): 2719-2726.

13. Slana, I., Liapi, M., Moravkova, M., Kralova, A. and Pavlik, I. (2009) Mycobacterium avium subsp. paratuberculosis in cow bulk tank milk in Cyprus detected by culture and quantitative IS900 and F57 real-time PCR. Prev. Vet. Med., 89: 223-226.

14. Sartor, R.B. (2005) Does Mycobacterium avium subspecies paratuberculosis cause Crohn's disease? Gut, 54: 896-898.

15. Atreya, R., Bulte, M., Gerlach, G.F., Goethe, R., Hornef, M.W., Heike, K., Meens, J., Mobius, P., Roeb, E. and Weiss, S. (2014) Facts, myths and hypotheses on the zoonotic nature of Mycobacterium avium subspecies Paratuberculosis. Int. J. Med. Microbiol., 304: 858-867.

16. Pillai, S.R. and Jayarao, B.M. (2002) Application of IS900 PCR for detection of Mycobacterium avium subsp. paratuberculosis directly from raw milk. J. Dairy Sci., 85: 1052-1057.

17. Bharathy, S., Gunaseelan, L., Porteen, K. and Prabu, K. (2014) Goat milk as a non - Invasive sample for confirmation of Mycobacterium avium subspecies paratuberculosis by IS900 PCR. J. Adv. Vet. Anim. Res., 1(3): 136-139.

18. Selim, A., El-Haig, M., Galila, E.S. and Gaede, W. (2013) Direct detection of Mycobacterium avium subsp. paratuberculosis in bovine milk by multiplex real time PCR. Anim. Sci. Pap. Rep., 31(4): 291-301.

19. Carvalho, I.A., Silva, A., Campos, V.E. and Moreira, M.A. (2009) Short communication: Detection of Mycobacterium avium subspecies paratuberculosis by polymerase chain reaction in bovine milk in Brazil. J. Dairy Sci., 92: 5408-5410.

20. Prabu, K. (2015) Comparative Evaluation of Diagnostic Assays in Establishing Status of Chronic Bacterial Zoonoses. M.V.sc. Thesis Submitted to Tamil Nadu Veterinary and Animals Sciences University, Chennai

21. Grant, J.R., Oriordan, L.M., Ball, H.J. and Rowe, M.T. (2001) Incidence of Mycobacterium avium subsp. paratuberculosis in raw sheep and goat's milk in England, Wales and Northern Ireland. Vet. Microbiol., 79: 123-131.

22. Corti, S. and Stephan, R. (2002) Detection of Mycobacterium avium subspecies paratuberculosis specific IS900 insertion sequences in bulk-tank milk samples obtained from different regions throughout Switzerland. BMC. Microbiol., 2(1): 15 .

23. Martinson, S., Hanna, P., Ikede, B., Lewis, J., Keefe, L.M. and McKenna, S. (2008) Comparison of bacterial culture, histopathology and immunohistochemistry for the diagnosis of Johne's disease in culled dairy cows. J. Vet. Diagn. Invest., 20: 51.

24. Dziedzinska, R.P., Slana, I., Lamka, J. and Pavlik, I. (2014) Influence of stress connected with moving to a new farm on potentially MAP infected mouflone. ISRN Microbiol. DOI: 10.1155/2014/450130.

25. Nielsen, S.S. and Toft, N. (2008) Ante mortem diagnosis of paratuberculosis: A review of accuracies of ELISA, interferon-gamma assay and faecal culture techniques. Vet. Microbiol., 129: 217-235.

26. Nielsen, S.S. (2008) Transition in diagnostic tests used for detection of Mycobacterium avium subspecies paratuberculosis infection in cattle. Vet. Microbiol., 132: 274-282.

27. Lucey, J.A. (2015) Raw milk consumption: Risk and benefits. Nutr. Today, 50(4): 189-193.

28. Little, C.L., Rhoades, J.R., Sagoo, S.K., Harris, J., Greenwood, M., Mithani, V., Grant, K. and Lauchlin, J.M. (2008) Microbiological quality of retail cheeses made from raw, thermized or pasteurized milk in the UK. Food Microbiol., 25: 304-312.

29. Claeys, W.I., Cardoen, S., Daube, G., Block, J.D., Dewettinck, K., Dierickd, K., Zutter, L.D., Huyghebaert, A., Imberechts, H. and Thiange, P. (2013) Raw or heated cow milk consumption: Review of risks and benefits. Food Control, 31: 251-262.

30. Singh, A.V., Singh, S.V., Singh, P.K. and Sohal, J.S. (2010) Is Mycobacterium avium subsp. paratuberculosis, the cause of Johne's disease in animals, a good candidate for Crohn's disease in man? Indian J. Gastroenterol., 29(2): 53-58.

31. Shankar, H., Singh, S.V., Singh, P.K., Singh, A.V., Sohal, J.S. and Greenstein, R.J. (2009) Presence characterization and genotype profiles of Mycobacterium avium subspecies paratuberculosis from unpasteurized individual and pooled milk, commercial pasteurized milk and milk products in India by culture, ELISA, PCR and PCR-REA methods. Int. J. Infect. Dis., 14: e121-e126. 